\title{
童岪 BeleidsonderzoekOnline
}

DOI: 10.5553/Beleidsonderzoek.000037

\section{Wat gemeenten van sociale wijkteams verwachten}

\author{
Silke van Arum en Vasco Lub
}

\author{
Aanbevolen citeerwijze bij dit artikel \\ Silke van Arum en Vasco Lub, 'Wat gemeenten van sociale wijkteams verwachten', \\ Beleidsonderzoek Online, februari 2014, DOI: 10.5553/Beleidsonderzoek.00oo37
}

\section{Inleiding}

In Nederland is in een kort tijdsbestek het fenomeen 'sociale wijkteams' opgekomen. De variëteit van deze teams is groot. Enkele kenmerken zijn dat ze interdisciplinair en integraal zijn. Zo werken in een sociaal wijkteam bijvoorbeeld uitvoerende professionals op het terrein van (geestelijke) gezondheid, welzijn, jeugdzorg en verwante beleidsterreinen samen in één team. Alternatieve benamingen zijn sociale teams, frontlijnteams, wijkzorgteams, multidisciplinaire samenwerkingsteams of kortweg 'wijkteams'. De gemeenten staan aan de vooravond van grote veranderingen met de transities en bezuinigingen. Steeds meer gemeenten hebben geconstateerd dat hulp voor zorgbehoevenden en zogenoemde multiprobleemgezinnen te gefragmenteerd is geworden. Vooral in aandachtswijken zouden de eigen specialismen, belangen en werkwijzen van sociale professionals adequate hulpverlening in de weg staan. Professionals zouden hierbij zijn verzonken in een hulpverleningsstructuur die niet slagvaardig werkt, waarbij bovendien de moeilijke gevallen tussen wal en schip raken. Verschillende gemeenten hebben daarom besloten de professionele krachten te bundelen. Het gaat dan onder meer om een betere uitwisseling tussen eerste en tweedelijns professionals, een betere doorverwijzing, en vormen van 'coproductie' met buurtbewoners. De manier waarop een sociaal wijkteam invulling krijgt, kan verschillen per gemeente. Maar de aanleidingen zijn hetzelfde: de komende transities in het sociale domein, de naderende bezuinigingen in de zorg en de behoefte aan een beter op elkaar afgestemde dienstverlening aan burgers die het alleen niet redden (zie VNG, 2013).

De verwachtingen over de sociale wijkteams zijn hooggespannen. Menig gemeente ziet het inzetten van de teams als dé nieuwe oplossing in de aanpak van sociale problematiek, vooral in aandachtswijken. Tientallen gemeenten hebben in een kort tijdsbestek dergelijke teams ingesteld. Maar wat beogen de diverse gemeenten nu precies met de wijkteams? Waar moet hun meerwaarde uit bestaan in de dienstverlening naar (kwetsbare) burgers? Geven gemeenten via de wijkteams invulling en kleur aan de decentralisatie van zorg- en welzijnstaken? 
Dit artikel gaat allereerst in op de verwachtingen over sociale wijkteams op basis van een analyse van 32 gemeentelijke beleidsnota's. Met deze analyse willen we bijdragen aan de verdere beleidsontwikkeling. Het openbaar bestuur in Nederland staat meer dan ooit voor de opgave om, in de woorden van Tops (2007), tot een 'regimevitalisering' te komen, waarbij een effectieve uitvoering centraal staat: het vermogen om dingen lokaal voor elkaar te krijgen. Voor de wijkteams is 2014 een cruciaal jaar. Aan de vooravond van de decentralisaties hebben de laatste voorbereidingen plaats, en er worden nieuwe contracten gesloten tussen gemeenten en zorg- en welzijnspartijen. Dat vraagt om helderheid over wat de gemeenten van de wijkteams verwachten. Hoewel het nog te vroeg is om conclusies te kunnen trekken over de effectiviteit van het werken met wijkteams, zijn er al wel experimenten en pilots geweest, waarover evaluatieonderzoeken zijn verschenen. Daarom gaan we in dit artikel op de tweede plaats na of de verwachtingen die uit de gemeentelijke nota's naar voren komen plausibel zijn, voor zover de beschikbare studies daar al iets over leren.

\section{Methode van onderzoek}

Voor dit onderzoek hebben we ons de volgende centrale vraag gesteld:

Wat zijn dominante veronderstellingen van gemeenten over de effecten en het functioneren van sociale wijkteams en hoe plausibel zijn die veronderstellingen, gegeven de beschikbare kennis?

Deelvragen hierbij zijn:

1. Wat zijn de veronderstelde verwachtingen over hun inzet?

2. Zijn deze verwachtingen voldoende onderbouwd?

3. In hoeverre blijven deze verwachtingen overeind na confrontatie met bestaand (wetenschappelijk) onderzoek en praktijkevaluaties?

4. Wat leren de inzichten over mogelijkheden om de wijkteams zo effectief mogelijk te laten zijn?

Voor het onderzoek zijn gemeentelijke beleidsnota's en bestaand onderzoek naar de sociale wijkteams geanalyseerd. De eerste stap bestond uit het inventariseren van de verschillende vormen van sociale wijkteams zoals deze worden ingezet in Nederland. Hiertoe is gebruikgemaakt van gemeentelijke beleidsnota's die direct toegankelijk waren. Op basis van een websearch, uitgevoerd in oktober 2013, is gezocht op termen zoals sociale wijkteams, frontlijnteams, multidisciplinaire teams, wijknetteams, sociale teams en wijkteams. Omdat sociale wijkteams ook schuilgaan achter lokaal-specifieke benamingen, heeft de zoektocht zich gericht op overeenkomstige structuren en uitgangspunten: arrangementen van sociale professionals, waarin interdisciplinaire samenwerking en een slagvaardigere dienstverlening aan kwetsbare burgers het uitgangspunt zijn.

Stap twee betrof een inventarisatie van de basale verwachtingen over de inzet van sociale wijkteams. Wat willen gemeenten en andere betrokkenen eigenlijk in 
beginsel bereiken met hun inzet? Deze inventarisatie heeft plaatsgevonden aan de hand van 32 gemeentelijke beleidsnota's. De nota's zijn gecodeerd naar argumentaties/assumpties van de wijkteams. Op basis van deze beschrijvingen zijn categorieën aangebracht. Voor het vaststellen van de meest dominante assumpties is vervolgens geteld in hoeveel beleidsnota's deze categorie voorkomt. Om de objectiviteit en daarmee de betrouwbaarheid van de bevindingen te vergroten hebben beide onderzoekers de categorisering en telling van elkaar gecontroleerd.

De derde stap bestond uit het verzamelen van inzichten uit de literatuur en bestaande (gemeentelijke) procesevaluaties, projectbeschrijvingen en kostenbatenanalyses van de wijkteams. Wat zeggen eerste evaluaties over de effecten van de wijkteams? En hoe aannemelijk zijn de veronderstelde verwachtingen? De inventarisatie van de evaluatieonderzoeken had plaats op basis van een websearch, bestaande contacten en een oproep aan de diverse gemeentelijke 'Wmo-werkplaatsen' om de bij hun bekende onderzoeken door te geven.

\section{Resultaten}

\subsection{Algemene observaties uit de nota's}

\section{Veel onduidelijk}

De eerste opvallende observatie is dat de wijkteam-nota's in het algemeen veel tekst bevatten, maar relatief weinig informatie. Gemeenten beargumenteren in de nota's nauwelijks waarom ze een sociaal wijkteam in het leven roepen, wat de doelstellingen zijn, welke problemen er in de wijken spelen, en op welke wijze de sociale wijkteams die problemen moeten oplossen. De beleidsnota's bezigen in dit verband vrij generiek ambtelijk taalgebruik, maar lichten zelden toe wat bepaalde uitgangspunten concreet inhouden. Bijvoorbeeld: 'Het sociaal wijkteam kijkt breed en integraal naar de vraag van de bewoner, waarbij wordt uitgegaan van de eigen kracht van de bewoner.' (G5) De nota's zijn daarbij weinig lokaal-specifiek. Een lokale contextualisering en probleembeschrijving blijft veelal achterwege. Op enkele uitzonderingen na bespreken de nota's geen specifieke doelgroepen, demografische gegevens die van belang kunnen zijn voor een adequate diagnose van de sociale situatie in een dorp of stad, of aanwezige maatschappelijke partijen die van belang kunnen zijn voor de samenstelling, functionering of institutionele inbedding van de wijkteams.

Een en ander weerhoudt de gemeenten er echter niet van een hoog ambitieniveau te formuleren als het gaat om wat teams voor elkaar moeten krijgen, welke competenties zij moeten hebben, welke muren zij moeten slechten, of waar zij kennis van moeten hebben. Maar in vrijwel geen enkel beleidsstuk wordt gerechtvaardigd waarop dat ambitieniveau is gebaseerd, en of een en ander in de praktijk ook kan worden gerealiseerd. De nota's hebben daardoor iets performatiefs. ${ }^{1}$ Zoals bijvoorbeeld in gemeente G14, die stelt: 'Er wordt uitgegaan van een sluitende keten (ketenregie).' Hoe die sluitende ketenregie moet worden bewerkstelligd - een uiterst complex thema waarover al decennia in de sociale en publieke sector wordt gedelibereerd - blijft ongewis.

\section{Tekstuele verwarring en contradicties}

Naast de onduidelijkheid is relatief vaak sprake van tekstuele verwarring en contradicties. Zijn de wijkteams nu gericht op korte of op langdurige zorg en 
ondersteuning of beide? Zijn ze generalistisch of juist specialistisch van inslag? Positioneert men ze in de eerste of vanuit de tweede lijn? Zijn de zware gevallen de doelgroep of juist de lichte gevallen? Is de benadering outreachend of juist vraaggericht? In de nota's lopen deze elementen vaak door elkaar heen, zonder dat eenduidige keuzes worden gemaakt. Slechts enkele gemeenten geven aan hoe de teams concreet moeten worden aangestuurd. De organisatorische en institutionele inbedding van de teams wordt soms onnodig gecompliceerd: in een gemeente komt er 'achter' het sociale team ook nog een doorzettingsteam, dat casusoverleg voert over 'moeilijke gevallen'. Maar wat is het verschil tussen deze twee teams? En hoe verhouden die professionele ketens zich tot elkaar? In een andere gemeente moet het sociale wijkteam samenwerken met het reeds bestaande wijknetwerk, dat qua samenstelling en werkwijze echter nauwelijks te onderscheiden is van het sociale wijkteam. Waarom blijven deze twee naast elkaar bestaan?

\subsection{Dominante assumpties over sociale wijkteams}

In de beleidsnota's zijn aan de hand van categorieën de dominante assumpties en achterliggende argumentaties rond de inzet van wijkteams gecodeerd. Figuur 1 geeft een overzicht van de categorieën en in hoeveel nota's deze voorkomen. Let wel: onderstaande categorieën representeren enkel de vermelding van een bepaalde assumptie of argumentatie. Het betekent niet dat die assumptie vervolgens ook duidelijk wordt geformuleerd of onderbouwd. Het mandaat dat de wijkteams moeten krijgen bij indicering, preventie of signalering (zie zevende categorie), wordt bijvoorbeeld verschillende keren aangestipt, maar niet duidelijk uiteengezet.

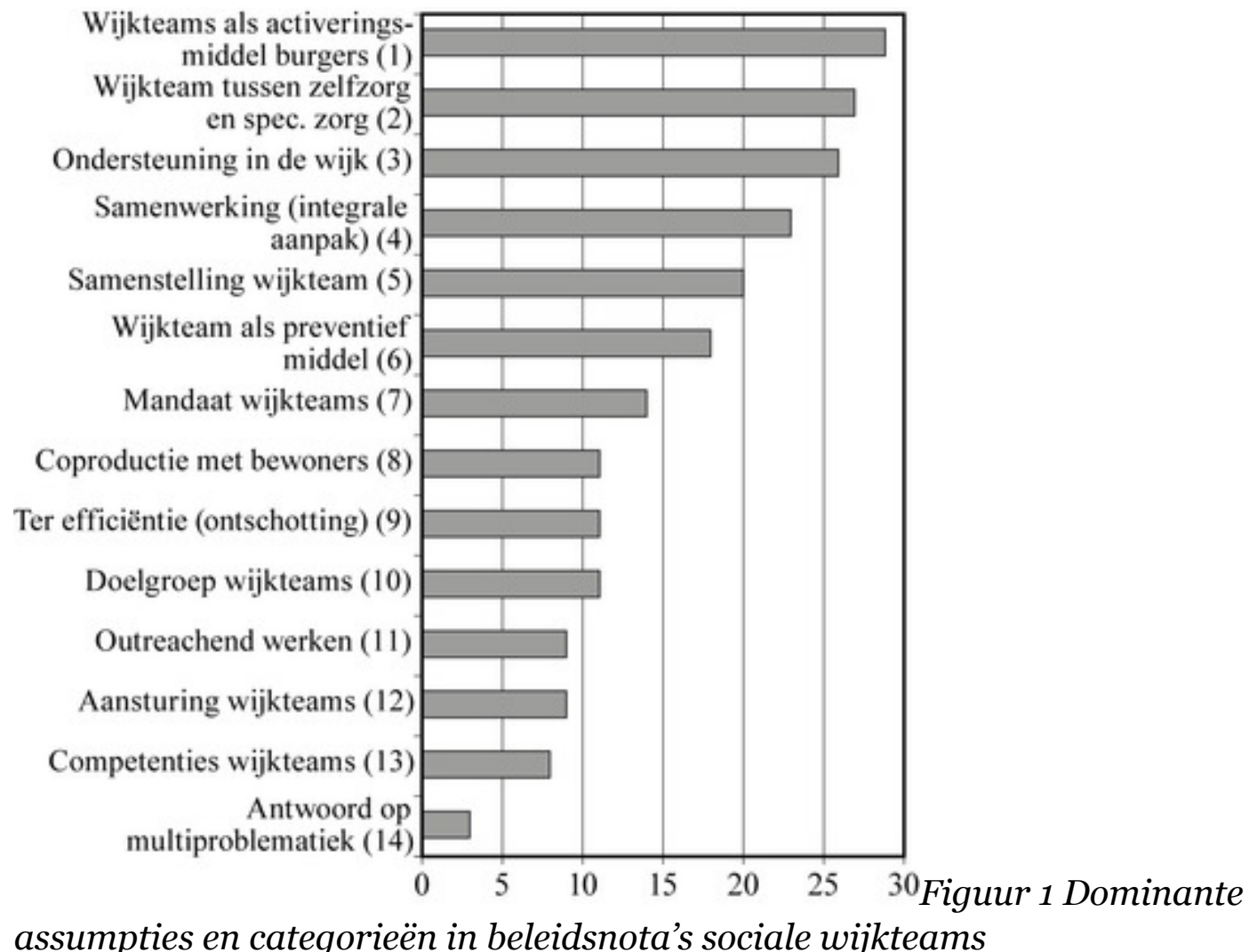

\section{Wijkteams vooral instrument voor burgeractivering}

Duidelijk wordt dat sociale wijkteams vooral worden gezien als een instrument voor activering c.q. zelfredzaamheid van burgers (zie de eerste drie categorieën). 
Anders gezegd: het burgerkracht-discours is dominant. Daardoor lijkt het uitgangspunt om de kwaliteit van de professionele hulpverlening (vooral tweedelijns) voor multiprobleemgezinnen te verbeteren van secundair belang te zijn. Het wijkteam als antwoord op de aanpak van multiproblematiek (meer dan één probleem) wordt nauwelijks expliciet genoemd in de nota's (zie laatste categorie).

Men zou gezien alle mediaberichtgeving verwachten dat de gemeenten de teams meer zouden presenteren als middel om tot betere afstemming te komen tussen sociale professionals voor probleemgevallen (vandaar samenwerking in een team), maar in de respectieve nota's is die argumentatie (samenwerking, korte lijnen) minder dominant.

De afgelopen jaren is met de veranderende verzorgingsstaat veel aandacht voor het stimuleren van burgerkracht. Dat wijkteams als middel worden gezien om met burgers vanuit hun kracht oplossingen te genereren, is op zich niet verrassend. De dominantie daarvan in de beleidsnota's (zie eerste categorie) in verhouding tot de beperkte aandacht voor multiproblematiek en ontschotting (respectievelijk op nummer 14 en 9) echter wel. We weten dat integraal, interdisciplinair en wijkgericht werken, waarbij zo veel mogelijk de eigen kracht van burgers en sociale netwerken wordt benut, niet gemakkelijk en vanzelfsprekend is. Er spelen vraagstukken rond organisatie, financiering, belangen van professionals en de rol van burgers, waarmee rekening gehouden moet worden. In het RMO-advies Burgerkracht (2011) pleitten De Boer en Van der Lans dan ook voor een systeeminnovatie, met enerzijds meer ruimte voor sociaal burgerschap en anderzijds een robuust vangnet voor kwetsbaren. In hun essay Burgerkracht in de wijk (2013) geven zij aan: 'Veler ogen zijn daarbij gericht op integraal, interdisciplinair, wijkgericht werken (één systeem, één plan, één professional, één budget) met een grote rol voor eigen kracht en de kracht van niet-professionele sociale netwerken.' Ze attenderen daarbij ook op de risico's die op de loer liggen als de institutionele schotten niet weggenomen worden: 'dat wijkteams uiteindelijk niet meer zijn dan een nieuw trucje in een voor het overige verkokerd sociaal domein' en 'de professionals in die wijkteams in een nieuwe setting op een oude manier hun werk gaan doen’.

Kijken we preciezer naar de burgerkracht-assumpties in de nota's, dan blijkt dat de wijkteams de taak meekrijgen die eerder al werd voorzien voor het welzijnswerk (zie bijvoorbeeld Welzijn versterkt burgerschap, Uyterlinde et al., 2007). Het gaat om het informeren en faciliteren van burgers hoe zij in hun eigen hulpvraag kunnen voorzien, al dan niet met ondersteuning van het eigen sociaal netwerk of buurtgenoten. Enkele gemeenten maken hierbij gebruik van het keukentafelgesprek of een leefzorgplan. Bij de meeste wordt echter niet geëxpliceerd hoe zij invulling geven aan het stimuleren van burgerkracht, zoals onderstaande fragmenten uit drie verschillende nota's illustreren.

'Frontlijnsturing en burgerkracht zijn de kern van de oplossing. Beide elementen komen terug in sociale wijkteams. Het versterken van het eigen verantwoordelijkheidsgevoel en de "zelfregie" van burgers en het activeren van de sociale omgeving zodat kwetsbare burgers kunnen (blijven) participeren in de eigen omgeving.' (G28)

'Het sociale wijkteam is het vliegwiel voor sociale vernieuwing. Voor een andere houding van uitvoerende professionals richting onze inwoners. Met deze andere houding zetten we in op meer kracht en zelfredzaamheid bij onze inwoners.' (G29) 
'Er worden Sociale Wijkteams ontwikkeld met als hoofddoel het stimuleren van inwoners om in hun directe omgeving en vanuit hun eigen kracht oplossingen te vinden voor problemen die zij ondervinden in het dagelijks leven. Daarnaast richten de teams zich op het stimuleren van inwoners om zich in te zetten voor hun buurt en medebewoners.' (G24)

In een deel van de nota's wordt 'burgerkracht' gezien als primaire oplossing voor professionele drukte (de situatie waarbij een verscheidenheid aan professionals over de vloer komt bij één gezin).

\begin{abstract}
'Kort samengevat wordt de professionele drukte teruggebracht tot een integrale aanpak waarbij aan de hand van zogenaamde keukentafelgesprekken een leefzorgplan wordt opgesteld dat start vanuit de mogelijkheden van de burger en zijn netwerk.' (G29)
\end{abstract}

Rondom aannames over de 'coproductie' van bewoners blijft het onduidelijk of daarmee samenwerking met de doelgroep(en) wordt bedoeld - bijvoorbeeld de professional trekt samen op met het probleemgezin - of dat het gaat om weerbare burgers die kwetsbare burgers ondersteunen, waarbij het wijkteam faciliteert of coördineert. Waarschijnlijk worden beide vormen beoogd.

\title{
Precieze inzet en institutionele inbedding wijkteams onduidelijk
}

Gemeenten positioneren wijkteams in het algemeen tussen zelfzorg en specialistische vormen van zorg (zie categorie 2 van figuur 1). In de eerste lijn dus, tussen de burgers (nulde lijn) en specialisten (tweede lijn) in. De gebruikte metaforen zijn interessant. In de nota's worden de wijkteams weergegeven als 'schakels', 'smeerolie', 'buffer', 'schil', 'spil', 'toegang' of 'vliegwiel'.

'De sociale wijkteams vormen de spil in de toegang naar ondersteuning op het gebied van werk, wonen, welzijn en zorg. Doordat leden van het sociaal wijkteam in de wijk aanwezig zijn, kennen ze de wijk en zetten zij direct in gang wat echt nodig is. Het sociale wijkteam krijgt hiervoor de mogelijkheden zodat ze slagvaardige en efficiënte ondersteuning mogelijk kunnen maken.' (G28)

Onduidelijk is hoe de positionering er concreet uitziet, welk mandaat wijkteams hebben voor doorverwijzing en of wijkteams als toegangspoort of juist als buffer moeten worden gezien voor specialistische vormen van hulp of zorg. Gelet op de nadruk op het activeren van burgers en de gebruikte formuleringen door de gemeenten moeten ze evenwel eerder als buffer dan als toegangspoort worden gekenschetst.

Sommige gemeenten zien wijkteams daarbij als generalisten die worden ondersteund door een pool van specialisten. Andere gemeenten willen juist dat wijkteams primair bestaan uit specialisten die door hun moederorganisaties (jeugdzorg, GGZ, enzovoort) de frontlinie in worden geschoven. Over welke kennis en vaardigheden moeten deze generalistische specialisten of generalisten beschikken? Wat moeten wijkteams in hun positie tussen de nulde en tweede lijn precies doen? In hoeverre verschilt hun inzet van generiek casusoverleg? En waarin verschillen wijkteams van de interventieteams of achter-de- 
voordeurteams? In de meeste gemeenten lijken dit verschillende teams, maar in andere gemeenten lijken ze samen te vallen. Vaak wordt verwezen naar de signalerings- en preventiefunctie die de wijkteams hebben, maar op basis van welke informatie zij dit moeten doen en hoe zij daaraan komen, wordt niet geconcretiseerd. Evenwel is onduidelijk hoe men wil voorkomen dat er in de nieuwe situatie niet alsnog verkokering ontstaat (vgl. hier Kruiter \& Pels, 2013). Nergens wordt bijvoorbeeld uiteengezet hoe de veel bekritiseerde institutionele schotten in de nieuwe situatie worden weggenomen.

\section{Bestaand onderzoek naar sociale wijkteams}

\section{Inhoudelijk onderzoek en quickscans}

Empirisch onderzoek op dit terrein is schaars. Dat is niet verrassend, gezien de betrekkelijk korte looptijd van de sociale wijkteams. Verschillende gemeenten zijn evenwel gestart met procesbeschrijvingen en maatschappelijke kostenbatenanalyses. De handvol bestaande analyses die thans beschikbaar zijn (veelal 'quickscans'), is vooral gericht op de systeemwereld waarin de teams zich bewegen en/of de financiële aspecten van hun inzet (zie bijvoorbeeld Sok et al., 2013; Goderie, 2013; De Meere et al., 2013). De quickscans lezen als de beleidsnota's zelf. De publicaties hebben een sterk sectorale focus. Gemeentebesturen en managementlagen van zorg- en welzijnsinstanties lijken de voornaamste lezersdoelgroepen. Het gaat vooral over de samenwerking van de professionele organisaties en de bestuurlijke aansturing; er wordt weinig tot niets vermeld over de gevolgen voor burgers. Wat ervaren doelgroepen die te maken hebben met sociale wijkteams? Worden zij er beter van? Waar lopen leden van een wijkteam tegenaan bij signalering, preventie of doorverwijzing? Die inhoudelijke analyse van de praktijk ontbreekt grotendeels. Hierdoor blijft de leefwereld van de uitvoeringspraktijk en van de burgers een blinde vlek. Hoewel sommige analyses wel vermelden dat er teamleden zijn geïnterviewd, is informatie hierover in de rapporten zelf zeer summier. Hun stem betreffende inhoudelijke ervaringen wordt daardoor nauwelijks gehoord. Een van de uitzonderingen is een klanttevredenheidsonderzoek van de gemeente Leeuwarden naar het functioneren van het 'frontlijnteam'. ${ }^{2}$ De resultaten van de enquête zijn overwegend positief: een ruime meerderheid van de geënquêteerde bewoners is bijvoorbeeld tevreden over het contact met de teams. Maar uit de publicatie valt niet op te maken waar dit contact uit bestaat, hoeveel respondenten hebben meegedaan, hoe deze zijn geworven, welke doelgroepen dit waren en hoe de vragenlijst is afgenomen. Een selectiebias of een sociaal wenselijke wijze van antwoorden is in dit verband dus niet uit te sluiten.

Een mogelijke verklaring voor de focus op de systeemwereld en financiële aspecten van de huidige onderzoeksrapporten naar de sociale wijkteams en het buiten beschouwing blijven van de leefwereld van professionals en burgers is de betrekkelijk korte looptijd van de teams. Op basis van een quickscan in Nijmegen concludeert Goderie (2013: 29) bijvoorbeeld: 'Van de resultaten van de casusuitvoeringen is in het kader van deze quickscan nog geen goed beeld te geven. Daarvoor is de periode gedurende welke de teams werkzaam zijn nog te kort. Weliswaar is er al een flink aantal casussen afgerond, maar veel casussen zijn nog in voorbereiding of uitvoering.' Ook het Verwey-Jonker Instituut wijst erop dat veel zaken rond de wijkteams zich nog moeten 'uitkristalliseren' en 'geregeld worden' (De Meere et al., 2013). Het kan ook zijn dat de huidige beleidsonderzoeken nog te zeer vervlochten zijn met onderzoeksvragen die vooral een bestuurlijk belang dienen (systeem en financiën), waardoor een meer 
inhoudelijke blik achterwege is gebleven.

\section{De vertekening van maatschappelijke kosten-batenanalyses}

Een populair meetinstrument om de effectiviteit van sociale wijkteams te beoordelen is de maatschappelijke kosten-batenanalyse (MKBA). Onder meer in Leeuwarden en Eindhoven zijn sociale wijkteams op deze wijze getoetst (zie LPBL, 2012; 2013). Aan MKBA's kleven echter belangrijke bezwaren. Bij een MKBA worden aannames over maatschappelijke effecten van de desbetreffende beleidsinterventie doorgerekend naar prognoses, en die prognoses worden vervolgens voorgesteld als feitelijke resultaten van de interventie (vervat in financiële kengetallen). Anders gezegd: een gewenste beleidstheorie wordt omgerekend naar een beleidsrealiteit in euro's. Een dergelijke manier van analyseren geeft een vertekend beeld omdat er geen bewijs wordt geleverd dat dergelijke resultaten zich ook werkelijk hebben gemanifesteerd, de verbanden tussen het beleid en de lange termijn effecten vaak vergezocht zijn, en er geen causaal verband kan worden aangetoond tussen investering en opbrengst. Die causale verbanden leggen de bestuurders of opstellers van de MKBA zelf. Bijvoorbeeld:

Door sociale wijkteams in probleemgezinnen neemt ook jeugdoverlast in de buurt af (aanname) > hierdoor hoeven politie en justitie minder vaak in actie te komen (prognose) > afgenomen inzet van politie/justitie levert X euro kostenbesparing op (op basis van aanname en prognose weergegeven verondersteld resultaat).

Ook bij de berekening van de zogeheten "immateriële effecten" van sociale wijkteams in een MKBA (uitgedrukt in euro's) worden aannames en prognoses naar veronderstelde resultaten getransformeerd. Bijvoorbeeld:

Door sociaal wijkteams komen X extra huishoudens in een financieel stabiele situatie terecht (aanname) > doordat zij minder stress ervaren, worden X 'gezonde' levensjaren gewonnen (prognose) > uitgaande van 20 duizend euro per gezond levensjaar, levert dat de maatschappij X miljoen euro aan baten op (op basis van aanname en prognose weergegeven verondersteld resultaat).

Discutabel is dat in de respectieve MKBA-rapporten de gewenste scenario's vervolgens worden weergegeven als behaalde resultaten, wat zich vervolgens uit in een conclusieformulering in de voltooid verleden tijd. Bijvoorbeeld:

"Uit de Maatschappelijke Kosten Baten Analyse blijkt dat 4 jaar frontlijnteam in Heechterp-Schieringen [Leeuwarden] een positief maatschappelijk saldo heeft opgeleverd van ruim $€ 2$ miljoen euro, netto contante waarde." (LPBL, 2012: 7)

We zijn niet de eersten die wijzen op de onzuiverheid van MKBA's. Ook in de infrastructurele hoek - waar de toetsingsmethode oorspronkelijk vandaan komt - bestaan al langer twijfels over de objectiviteit en het nut ervan (zie bijvoorbeeld Beukers et al., 2011). Maar de weeffouten die zich manifesteren in de rekenmethode zelf - aannames worden weergegeven als behaalde resultaten die worden voorgesteld als financiële baten - worden naar ons idee nog steeds te weinig (h)erkend. De toenemende populariteit van MKBA's in het sociale 
domein - zie bijvoorbeeld ook de woningcorporatiesector - is desondanks verklaarbaar en begrijpelijk. Ten tijde van bezuinigingen en twijfels over sociale investeringen willen bewindvoerders en belanghebbenden laten zien dat investeringen op sociaal gebied meer dan luxe zijn en geld opleveren. Een MKBA biedt hiervoor het 'tastbare' bewijs. Maar het feit dat in de sociale en publieke sector op basis van bovenstaande formuleringen MKBA's worden aangewend om de effectiviteit van methoden en beleid aan te tonen, is desondanks zorgelijk.

In het beste geval levert een MKBA enkel informatie op over de kosten van bepaalde outputactiviteiten. Als er bijvoorbeeld $\mathrm{X}$ procent minder doorverwijzingen zijn door de inzet van wijkteams, of Y procent burgers doet het sinds hun inzet op "eigen kracht", dan kan worden berekend hoeveel in de nieuwe situatie bespaard is ten opzichte van eerdere professionele arrangementen. Maar dergelijke informatie wil natuurlijk niet zeggen dat daarmee ook de problematiek van de doelgroep is opgelost (efficiency staat niet gelijk aan effectiviteit). Om dat vast te stellen is empirisch onderzoek nodig. Door de doelen van sociale wijkteams vaag te houden kunnen bovendien bepaalde gewenste uitkomsten (bijvoorbeeld X\% minder huisuitzettingen) in een MKBA worden toegeschreven aan het conto van de wijkteams, zonder dat duidelijk is of het verband tussen wijkteams en huisuitzettingen empirisch is te rechtvaardigen.

\section{Conclusies en aanbevelingen}

Over de inzet, het functioneren en de effectiviteit van sociale wijkteams blijft na aanleiding van deze verkenning nog veel onduidelijk. De beleidsnota's zijn daarvoor veelal nog te vaag. Of het enthousiasme voor sociale wijkteams door de ervaringen gesteund zal worden, is daarom vooralsnog moeilijk te beantwoorden. Deze verkenning biedt evenwel aanleiding voor enkele kritische kanttekeningen en aanbevelingen.

\section{Beleidsnota's}

De verschillende gemeentelijke nota's zijn nogal oppervlakkig en eenvormig. Dat met het oog op het welslagen van sociale wijkteams de beleidsnota's helder moeten zijn, is evident. Zij dienen als anker: een schriftelijk basis waarop de betrokken partijen kunnen terugvallen en hun handelen kunnen legitimeren. Het vraagt om duidelijkheid over welke acties ondernomen worden, waarom (legitimatie), door wie (uitvoering), hoe (middelen) en wanneer (tijdsplanning). Gebrek aan visie is problematisch; als de nota's hierover al verwarring zaaien, hoe dan te verwachten dat de samenwerking tussen uitvoerende professionals in de praktijk wél helder en goed verloopt? Daarnaast brengt onduidelijkheid van beleidsnota's het risico van willekeur in de uitvoering met zich mee. Maak in de beleidsnota duidelijk waar het wijkteam toe dient: wat zijn de problematiek en gewenste situatie? Waar stuur je als gemeenten op? Wat heeft prioriteit? Tot slot zijn de nota's belangrijk met het oog op transparantie en verantwoording. Waar beoordeel je wijkteams op of reken je ze op af, als doelen en doelgroepen niet helder zijn geformuleerd? De gewenste situatie moet in termen van doelstellingen worden geschetst omdat anders het toetsen (beoordelen) van de effecten van het beleid niet mogelijk is (Van den Heuvel, 1998). Die doelen hoeven niet in steen gebeiteld te zijn, want in zo'n veranderende wereld is het belangrijk ruimte te laten om op grond van ervaring het beleid bij te stellen. 
Het bestaande onderzoek naar de wijkteams geeft onvoldoende zicht op wat deze omslag betekent in de uitvoering en leefwereld van de burgers. De vraag of burgers beter geholpen worden, blijft voor nu onbeantwoord. Een mogelijke verklaring daarvoor is de (te) korte looptijd van de sociale wijkteams, die nog in de fase van pilots en experimenten zit. Een fase om uit te proberen, terugblikken, leren en implementeren. Maar met de decentralisaties voor de deur zit bij de gemeenten de vaart erin en gaat uitproberen veelal in één beweging door naar uitrollen, waardoor het lerend vermogen beperkt blijft en praktijkervaringen onvoldoende meegenomen worden in het bijstellen van het beleid. Gemeenten moeten blijven nadenken over de vraag welke doelgroepen met welke problematiek, op welke manier het beste ondersteund kunnen worden. Men zou overigens kunnen beweren dat deze lokale inkleuring in de praktijk wél gestalte krijgt. Wellicht weten de teams op straat en thuis bij de burgers de goede vorm te vinden. Dat zal onafhankelijk, empirisch praktijkonderzoek moeten uitwijzen.

\section{Beleidsontwikkeling en toekomstig onderzoek naar wijkteams}

Wij stellen voor dat beleidsontwikkeling en toekomstig onderzoek naar sociale wijkteams zich richt op vier spectra (zie tabel 1). De 'kernvragen van beleid' zoals ontwikkeld door Hemerijck (2003) ${ }^{3}$ kunnen daarbij als leidraad dienen. Ten eerste is het van belang dat scherper wordt gekeken naar de instrumentele doelmatigheid van sociale wijkteams (effectiviteitsvraag). Zijn burgers met deze wijkteams beter af dan voorheen? En waar is hun werkzaamheid van afhankelijk? Ten tweede moet de maatschappelijke aanvaardbaarheid van dominante vertrekpunten van wijkteams in kaart worden gebracht (morele vraag). Zoals is gebleken, worden wijkteams vooral gelegitimeerd als activeringsmiddel van burgerkracht. Maar in hoeverre zijn burgers inderdaad warm te maken voor coproducties met sociale professionals? En wat kunnen probleemgezinnen op 'eigen kracht'? Ten derde is een toetsing van de institutionele haalbaarheid van belang (uitvoeringsvraag). De betrokken professionals en hun organisaties kennen hun eigen bedrijfscultuur en bestuurlijke kaders. Oude gewoontes, maar ook structuren, ingesleten werkwijzen en wetgeving zijn niet van de een op andere dag om te buigen, wat ongetwijfeld gevolgen heeft voor een soepele samenwerking tussen professionals in de frontlinie. Dit heeft op zijn beurt gevolgen voor de zo gewenste ontschotting. Het risico bestaat dat wijkteams op papier integraliteit uitstralen, maar in de praktijk 'meer van hetzelfde' betekenen (vgl. Kruiter \& Pels, 2013). Ook kan men zich in dit verband afvragen hoe uitvoerende zorg- en welzijnsprofessionals de transitie moeten maken van specialist naar generalist.

Tabel 1Spectra voor beleidsontwikkeling en -onderzoek naar sociale wijkteams (de kernvragen zijn naar Hemerijck, 2003)

\section{Beleidsspectrum Kernvraag Onderzoeksvraag Thema's voor wijkteams}

Wat zijn de (middel)lange termijn effecten van de teams op de beoogde doelgroepen? Wordt

Instrumentele doelmatigheid de hulpverlening voor probleemgezinnen effectiever wanneer de 


\begin{tabular}{|c|c|c|c|}
\hline & & & $\begin{array}{l}\text { professionele krachten } \\
\text { worden gebundeld? } \\
\text { Worden zij er beter } \\
\text { van? }\end{array}$ \\
\hline $\begin{array}{l}\text { Maatschappelijke } \\
\text { aanvaardbaarheid }\end{array}$ & Morele vraag & Hoort het? & $\begin{array}{l}\text { Zijn burgers warm te } \\
\text { maken voor } \\
\text { coproductie met } \\
\text { sociale professionals? } \\
\text { Waar hangt hun inzet } \\
\text { vanaf? In hoeverre } \\
\text { kunnen doelgroepen } \\
\text { het op 'eigen kracht'? }\end{array}$ \\
\hline $\begin{array}{l}\text { Institutionele } \\
\text { haalbaarheid }\end{array}$ & Uitvoeringsvraag & Kan het? & $\begin{array}{l}\text { Zijn de institutionele } \\
\text { randvoorwaarden } \\
\text { aanwezig voor } \\
\text { vergaande } \\
\text { intersectorale } \\
\text { samenwerking? Vraagt } \\
\text { de generalistische } \\
\text { inslag van de teams om } \\
\text { andere professionele } \\
\text { kennis, attitudes en } \\
\text { vaardigheden? In } \\
\text { hoeverre zijn die } \\
\text { vaardigheden thans } \\
\text { aanwezig bij eerstelijns } \\
\text { beroepskrachten? }\end{array}$ \\
\hline $\begin{array}{l}\text { Constitutionele } \\
\text { rechtmatigheid }\end{array}$ & Juridische vraag & Mag het? & $\begin{array}{l}\text { Hoe verhoudt de } \\
\text { werkwijze van sociale } \\
\text { wijkteams zich tot } \\
\text { wetgeving over } \\
\text { gegevensuitwisseling } \\
\text { en de bescherming van } \\
\text { persoonsgegevens? In } \\
\text { hoeverre speelt de } \\
\text { afhankelijkheidspositie } \\
\text { van burgers in } \\
\text { aandachtswijken ten } \\
\text { opzichte van instanties } \\
\text { een rol bij noties rond } \\
\text { rechtvaardigheid in } \\
\text { zorg, hulpverlening en } \\
\text { controle? }\end{array}$ \\
\hline
\end{tabular}

Tot slot behoeft de constitutionele rechtmatigheid van de werkwijze van sociale wijkteams aandacht (juridische vraag). Het juridisch adviesorgaan Socversity (2011: 2) wijst in dit verband op enkele belangwekkende risico's. Medewerkers van een sociaal wijkteam proberen een vertrouwelijke sfeer met de burger in zijn/haar eigen huis te creëren. De medewerker moet proberen een relatie op te bouwen, zodat de burger ook meer over zichzelf gaat vertellen. De vraag is echter: met wie praat de burger op dat moment? Met een welzijnswerker, een zorgverlener, iemand van de sociale dienst? De burger weet het niet, omdat al 
deze verschillende disciplines zijn samengebracht in een sociaal wijkteam. Tot het moment dat de in vertrouwen gegeven informatie wordt gedeeld met betrekking tot een mogelijk strafbaar feit. Dan kan blijken dat de maatschappelijk werker heeft doorgegeven aan de sociale dienst dat een maand is samengewoond zonder dat dit bij de dienst is gemeld (Socversity, 2011: 2). We beweren niet dat dergelijke situaties in de praktijk reeds voorkomen. Maar het is een denkbaar scenario waarmee leden van een sociaal wijkteam kunnen worstelen. Wat doe je met informatie dat in vertrouwen met jou is gedeeld? Deel je alle kennis met je team? En wat doen die er vervolgens mee? Heb je daar nog grip op?

\section{Tot besluit}

De conclusies van voorliggend artikel hebben vooral een agenderende functie. De sociale en publieke sector hebben soms de neiging zich te verliezen in 'innovaties' en hypes die, achteraf gezien, gebaat waren geweest bij meer bezinning. Sociale wijkteams kunnen een goed idee zijn. Maar uit de notaanalyse blijkt dat gemeenten zich meer rekenschap kunnen geven van de instrumentele, maatschappelijke, institutionele en constitutionele aspecten die met hun inzet gemoeid zijn. Voorkomen moet worden dat het beleidsmiddel 'sociale wijkteam' tot doel verwordt. Het zou goed zijn als gemeenten helder aangeven waarvoor in hun gemeente een sociaal wijkteam nodig is (en waarvoor niet). Welke doeleinden worden nagestreefd, zijn deze toereikend en uitvoerbaar, en hoe bedienen zij de doelgroep? Daarmee bedoelen we overigens niet dat alles helemaal dichtgetimmerd moet worden. De decentralisaties en de bezuinigingen zorgen voor een complexe herziening voor kwetsbare groepen burgers. Die herziening moet op een doordachte manier worden ingevoerd, en door parallel daaraan onderzoek te doen, kan de aanpak waar nodig worden bijgesteld. Met als resultaat dat we niet over een aantal jaren tot de conclusie komen dat de inzet van sociale wijkteams onvoldoende effectief is gebleken.

Noot: Onze dank gaat uit naar Saskia Keuzenkamp (Movisie), Ard Sprinkhuizen (Hogeschool Inholland) en Tom van Yperen (Nji) voor hun inbreng gedurende het onderzoek en commentaar op de eerdere versie van de tekst. En naar Bard Briels en Els Kok (Movisie) voor de websearch naar de gemeentelijke beleidsnota's en evaluatieonderzoeken.

\section{Literatuur}

Beukers, E., Bertolini, L., \& Brömmelstroet, M. te. (2011). Knelpunten in het $M K B A-p r o c e s$. Den Haag: NICIS.

Bewoners over het frontlijnteam Leeuwarden, 2012.

Boer, N. de, \& Lans, J. van der. (2011). Burgerkracht. De toekomst van het sociaal werk in Nederland. Den Haag: Raad voor Maatschappelijke Ontwikkeling.

Boer, N. de, \& Lans, J. van der. (2013). Burgerkracht in de wijk. Sociale wijkteams en de lokalisering van de verzorgingsstaat. Den Haag: Platform 31.

Goderie, K. (2013). De start van de sociale wijkteams in Nijmegen. Verslaggeving quickscan een jaar na de aftrap. Gemeente Nijmegen. 
Hemerijck, A. (2003). Vier kernvragen van beleid. Beleid en Maatschappij, 3o, 3-19.

Indicatieve MKBA Wijeindhoven. LPBL, 2013.

Heuvel, J.H.J. van den. (1998). Beleidsinstrumentatie. Sturingsinstrumenten voor het overheidsbeleid. Utrecht: Uitgeverij Lemma.

Kruiter, A.J., \& Pels, C. (2013). De dag dat Peter de deur dichttimmerde. Waarom mensen die onze hulp het hardst nodig hebben niet geholpen worden. Amsterdam: Van Gennip.

Meere, F. de, Hamdi, A., \& Deuten, J. (2013). Het is de integrale aanpak die werkt. Evaluatie na één jaar Utrechtse Buurtteams Krachtig. Utrecht: VerweyJonker Instituut.

MKBA Frontlijnteam Heechterp-Schieringen (Leeuwarden). LPBL, 2012.

Sociale wijkteams in ontwikkeling. Inrichting, aansturing en bekostiging. VNG, 2013.

Socversity. (2011). Enkele juridische aspecten van de werkwijze van de sociale wijkteams. Leeuwarden: Socversity.

Sok, K., Bosch, A. van den, Goeptar, H., Sprinkhuizen, A., \& Scholte, M. (2013). Samenwerken in de wijk. Actuele analyse van sociale wijkteams. Utrecht: Movisie.

Tops, P. (2007). Regimeverandering in Rotterdam. Hoe een stadsbestuur zichzelf opnieuw uitvond. Amsterdam: Atlas.

Uyterlinde, M., Neefjes, K., \& Engbersen, R. (2007). Welzijn versterkt burgerschap. Utrecht: MOVISIE.

Walzer, M. (1983). Spheres of justice. A defense of pluralism and equality. New York: Basic Books.

\section{Noten}

1 Performatief is een term uit de taalkunde en retorische filosofie, beter bekend als management by speech.

2 Zie de pdf Bewoners over het frontlijnteam Leeuwarden, 2012.

3 Met dank aan Jurriaan Omlo. 
